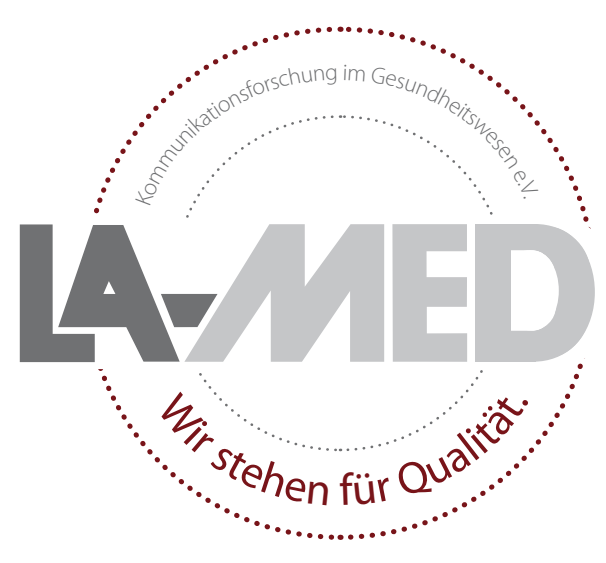

\section{Sie lesen Qualität}

Damit das auch so bleibt, befragen wir Sie in Kooperation mit tns infratest in den nächsten Wochen.

Ihr Urteil ist uns wichtig. Bitte nehmen Sie teil!

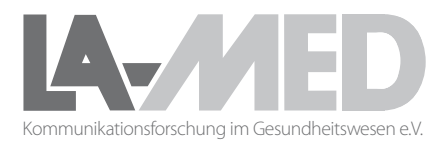

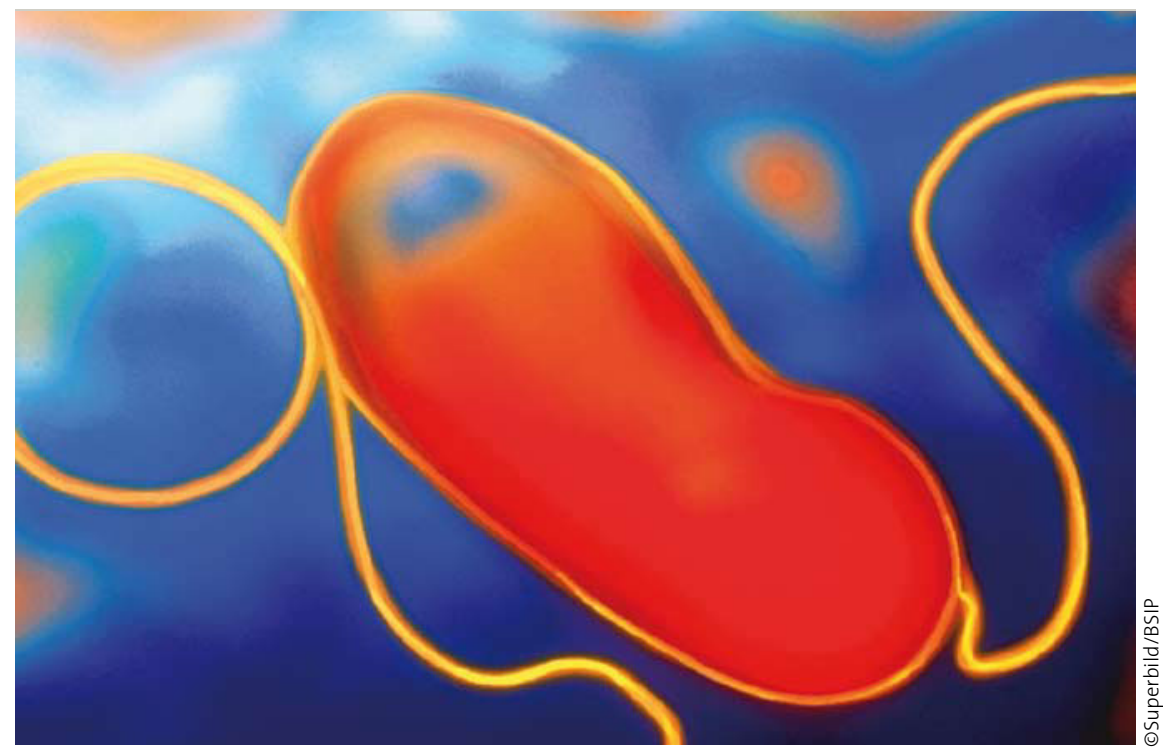

Wird H. pylori eradiziert, kann sich manchmal auch eine Eisenmangelanämie bessern.

\title{
Helicobacter-pylori-Infektion verursacht systemische Entzündung
}

\section{Helicobacter pylori spielt bei einer Reihe von Magenerkrankungen (Ulkus, Karzinom, MALT-Lymphom, Riesenfaltengastritis) eine entschei- dende pathogenetische Rolle. Dass dieser Keim darüber hinaus auch einen systemischen Entzündungs- prozess induziert, dafür sprechen die Ergebnisse einer epidemiologischen Studie.}

- Dabei handelt es sich um eine bevölkerungsbasierte Untersuchung mit 2361 Teilnehmern. Bei ihnen wurde die Helicobacter-pylori-Infektion serologisch nachgewiesen.

Ziel der Untersuchung war es, eine mögliche Verknüpfung zwischen der Helicobacter-pylori-Infektion und der Erhöhung des C-reaktiven Proteins nachzuweisen bzw. auszuschließen. Nach Adjustierung von Geschlecht, Alter, Körpergröße, Rauchgewohnheiten und sozioökonomischen Status bestand bei Helicobacter-pylori-infizierten Personen häufiger ein signifikant erhöhtes Serum-CRP (> $3 \mathrm{mg} / \mathrm{l})$.

\begin{abstract}
Kommentar
Dass die Helicobacter-pylori-Infektion nicht nur eine Magenerkrankung ist, sondern auch systemische Komplikationen bzw. Erkrankungen induzieren kann, wird seit Langem vermutet. Diskutiert wird ein Zusammenhang z.B. bei Hauterkrankungen wie der chronischen Urtikaria. Aber auch bei Patienten mit einer unklaren chronischen Eisenmangelanämie, bei denen eine Blutungsquelle ausgeschlossen ist, dürfte die systemische Entzündung eine Rolle spielen; denn der durch Helicobacter pylori induzierte chronische Entzündungsreiz führt zu einer vermehrten Bildung des Eisenhormons Hepcidin in der Leber, welches wiederum die Eisenresorption im Darm hemmt. Erste klinische Studien zeigen, dass zumindest bei einem Teil solcher Patienten durch eine Eradikation die Anämie gebessert bzw. geheilt werden kann.
\end{abstract}

P. StiefelhageN =

\footnotetext{
- L. Jackson et al.

A population-based epidemiologic study of Helicobacter pylori infection and its association with systemic inflammation. Helicobacter 14 (2009) 460-465
} 